\title{
Phase I clinical study of a personalized peptide vaccination available for six different human leukocyte antigen (HLA-A2, -A3, -A11, -A24, -A31 and -A33)-positive patients with advanced cancer
}

\author{
AKIRA YAMADA ${ }^{1}$, MASANORI NOGUCHI $^{2,4}$, NOBUKAZU KOMATSU ${ }^{3}$, SHIGETAKA SUEKANE $^{4}$, \\ SHIGERU YUTANI ${ }^{3}$, FUKUKO MORIYA ${ }^{4}$, TAKASHI MINE ${ }^{3}$, KOSUKE MOMOZONO ${ }^{4}$, \\ KOICHIRO KAWANO 5 and KYOGO ITOH ${ }^{3}$
}

\begin{abstract}
Divisions of ${ }^{1}$ Cancer Vaccine Development, and ${ }^{2}$ Clinical Research, Research Center for Innovative Cancer Therapy; Departments of ${ }^{3}$ Immunology and Immunotherapy, ${ }^{4}$ Urology, and ${ }^{5}$ Obstetrics and Gynecology, Kurume University School of Medicine, Kurume, Fukuoka 830-0011, Japan
\end{abstract}

Received October 1, 2010; Accepted December 2, 2010

DOI: $10.3892 / \mathrm{etm} .2010 .177$

\begin{abstract}
The majority of peptide-based cancer vaccines under development are for human leukocyte antigen (HLA)-A2- or -A24-positive patients. To overcome this limitation, we conducted a phase I clinical study of peptide vaccines designed for cancer patients with six different HLA-A types. Eligible patients were required to have failed prior standard cancer therapies and to be positive for the HLA-A2, -A24 or -A3 (A3, A11, A31 and A33) supertype. Three sets of 8 candidate peptides ( 24 peptides in total) were provided for vaccination to $\mathrm{HLA}_{-\mathrm{A} 2}{ }^{+}$, HLA-A24 ${ }^{+}$ and $\mathrm{HLA}-\mathrm{A} 3^{+}$patients, respectively. Personalization of the vaccination peptides from the candidate pool was made by considering the patients' HLA types and pre-existing levels of IgGs to the candidate peptides. Seventeen patients were enrolled in this study. The peptide vaccinations were well tolerated in all patients with no vaccine-related severe adverse events. Augmentation of cytotoxic T lymphocyte (CTL) or IgG responses specific to the vaccinated peptides was observed in 11 or 10 out of 13 cases tested, respectively. This new type of vaccine is recommended for phase II clinical trial because of its tolerability and the immune responses to the vaccinated peptides.
\end{abstract}

Correspondence to: Dr Akira Yamada, Cancer Vaccine Development Division, Kurume University Research Center for Innovative Cancer Therapy, Kurume, Fukuoka 830-0011, Japan

E-mail: akiymd@med.kurume-u.ac.jp

Abbreviations: CTL, cytotoxic T lymphocyte; HLA, human leukocyte antigen; PBMCs, peripheral blood mononuclear cells

Key words: personalized, cancer vaccine, peptide, clinical trial, phase I

\section{Introduction}

Immunotherapy is one of the most promising modalities for cancer treatment. Identification of T-cell epitopes of cancer antigens enables the development of peptide-based cancer vaccines. More than 200 T-cell epitopes of cancer antigens have been identified, and clinical trials using these peptides are in progress at various institutions with promising results $(1,2)$.

It is well known that recognition of cancer antigens by T-cell receptors is restricted by class I-human leukocyte antigen (HLA) molecules, and epitope peptides recognized by T-cells differ according to the HLA type of the patients (1-5). This fact, together with the presence of many different types of class I-HLAs, hampers the development of peptide-based cancer vaccines at the industrial level $(1,2)$.

Currently, peptide-based cancer vaccines are mainly developed for HLA-A2 $2^{+}$or HLA-A24 $4^{+}$patients and rarely developed for the other types of class I-HLAs $(1,2)$. The approximate frequencies of the HLA-A2 and -A24 populations are as follows: 40 and 60\% in Japanese, 50 and $20 \%$ in Caucasians, and 30 and $12 \%$ in African blacks, respectively (6). Therefore, the currently developed HLA-A2 and -A24 vaccines only cover $76 \%[40+60 \% \times(100-40) / 100 \%]$ of Japanese, $60 \%$ of Caucasians and 38\% of African blacks, and development of new vaccines for the other types of class I-HLAs is required. After HLA-A2 or -A24, the most frequent class-I HLA types in Japanese are HLA-A26 and -A11 (occurring in approximately $20 \%$ of the population), followed by -A31 and -A33 ( 15\%) (6). HLA-A11, -A31 and -A33, as well as $-\mathrm{A} 3$, make up the $\mathrm{A} 3$ supertype, and common binding motifs of antigenic peptides for these HLA types have been identified (7).

In the present study, to overcome HLA-based limitations in the development of peptide vaccines, three sets of 8 candidate peptides (24 peptides in total) were provided for vaccination to HLA-A2 ${ }^{+}$, HLA-A24 $4^{+}$and HLA-A $3^{+}$patients, respectively. Personalization of the vaccination peptides from the candidate 
peptide pool was conducted by considering the HLA types of the patient and the pre-existing levels of IgGs to the candidate peptides $(1,2,8-10)$, and the safety and immunological effects of the vaccination were analyzed.

\section{Patients and methods}

Patients. Between April 2007 and September 2008, 17 patients with different types of HLA-A alleles and different types of cancers who visited the outpatient clinic of Kurume University Hospital were enrolled in this study. The study was approved by the Kurume University Ethics Committee and was registered in UMIN-CTR (UMIN000000619). Eligibility criteria of the patients were as follows. i) Patients were pathologically diagnosed with cancer which was refractory to standard cancer therapies; ii) patients possessed target lesions for evaluation of response; iii) patients were positive for HLA-A2, -A3, -A11, -A24, -A31 or -A33; iv) patients had significant levels of plasma IgGs reactive to at least one of the vaccine candidate peptides; and v) any patients who previously received pre-therapies, including chemotherapy, immunotherapy or radiation therapy, started vaccine therapy more than 4 weeks after the last treatment. In the case of 5-FU and 5-FU-related compounds, the vaccine therapy started after a washout period of more than 2 weeks, and patients did not exhibit any remaining anti-tumor effects or adverse effects of pre-therapy at the time of vaccine therapy; vi) patients had an Eastern Cooperative Oncology Group (ECOG) performance status score of $0-2$; vii) patients were expected to survive more than 3 months; viii) patients satisfied the following: WBC $\geq 3,000 / \mathrm{mm}^{3}$, lymphocytes $\geq 1,000 / \mathrm{mm}^{3}, \mathrm{Hb} \geq 9.0 \mathrm{~g} / \mathrm{dl}$, platelets $\geq 100,000 / \mathrm{mm}^{3}$, serum creatinine $\leq 1.4 \mathrm{mg} / \mathrm{dl}$ and total bilirubin $\leq 1.5 \mathrm{mg} / \mathrm{dl}$; ix) patients were negative for hepatitis virus $\mathrm{B} / \mathrm{C}$; $\mathrm{x}$ ) patients were more than 20 years and less than 80 years of age; and $\mathrm{xi}$ ) all of the patients provided written informed consent prior to study entry.

The following patients were excluded from the study: i) patients with severe symptoms (active or severe infectious, circulatory, respiratory or kidney disease, immunodeficiency and disturbance of coagulation); ii) patients with a past history of severe allergic reactions; iii) patients who were pregnant or nursing, or who were currently attempting to become pregnant. (This included patients who had failed to use effective contraception during or for at least 70 days after study participation.) and iv) patients who were judged inappropriate for the clinical trial by doctors.

Clinical protocol. This was an open-label phase I study. The primary endpoint of this study was adverse events (evaluation of safety) and the secondary endpoint was immunological effects of group 3 peptides (see Peptides and vaccine preparation). Plasma levels of IgGs specific to the 24 different vaccine candidate peptides were measured for screening. Based on the results of the HLA typing and the IgG screening, peptides showing higher immune responses (a maximum of 4 peptides) were selected from an appropriate group(s) of candidate peptides for injection as reported previously (8-10). If two groups of candidate peptides were appropriate for a patient, a maximum of 2 peptides were selected from each group. The peptides ( $3 \mathrm{mg} /$ peptide) were subcutaneously injected with incomplete Freund's adjuvant (IFA) once a week for 6 weeks as reported previously (8-10). We investigated immunological responses to the vaccinated peptides after every six vaccinations. After the 6th vaccination, the vaccinated peptides were re-selected according to the results of immunological tests. Physical examination was performed weekly throughout the entire treatment period. Complete blood counts and serum chemistry tests were performed once every 2 weeks. All the vaccinated patients $(n=17)$ were assessed for toxicity. Thirteen patients whose samples were available both pre- and post- (after the 6th) vaccination were assessed for immunological responses. Toxicity was assessed according to the common toxicity criteria for adverse events (CTCAE) version 3.0.

Peptides and vaccine preparation. Three sets of 8 candidate peptides (24 peptides in total) were provided for vaccination to HLA-A2 ${ }^{+}$, HLA-A $24^{+}$and HLA-A $3^{+}$supertype patients, respectively. The peptide name, 'mother' protein name, amino acid (a.a.) positions in the protein and a.a. sequences are provided in Table I.

The peptides were prepared under the conditions of Good Manufacturing Practice by the PolyPeptide Laboratories (San Diego, CA, USA) and the American Peptide Company (Vista, CA, USA). The safety and immunological effects of the HLA-A2 and -A24 peptides were confirmed in previously conducted clinical studies (8-10). By contrast, the 8 peptides included in the pool for the HLA-A3 supertype were not previously used in clinical trials, although these peptides were previously shown to induce cytotoxic $\mathrm{T}$ lymphocyte (CTL) activity in vitro in HLA-A $3^{+}$supertype cancer patients (11-13).

The peptides were dissolved in the appropriate solvents and stored at $-80^{\circ} \mathrm{C}$. The stock solutions were diluted with saline, sterilized by filtration and mixed with an equal volume of IFA to make the emulsion preparation. The IFA formulation designated as 'NH2' consisted of sorbitan monooleate (NOFABLE SO-991; NOF Corporation, Tokyo, Japan) $11.4 \mathrm{w} / \mathrm{w} \%$ and mineral oil (Hicall M-72; Kaneda, Tokyo, Japan) 88.6 w/w\%. NOFABLE SO-991 and Hicall M-72 are pharmaceutical-grade products, and their regulatory status meets the requirements of the Japanese Pharmaceutical Excipients and the Japanese Pharmacopeia, respectively.

Peptide-specific CTL response. Screening of peptide-specific CTL precursors was conducted using $30 \mathrm{ml}$ of peripheral blood obtained from each patient. Peripheral blood mononuclear cells (PBMCs) were separated by means of Ficoll-Conray density gradient centrifugation. Peptide-specific CTL responses in PBMCs were detected using a previously reported culture method (14). Briefly, PBMCs ( $1 \times 10^{5}$ cells/ well) were incubated with $10 \mu \mathrm{M}$ of a peptide in $200 \mu \mathrm{l}$ of culture medium in U-bottom-type 96-well microculture plates (Nunc, Roskilde, Denmark). The culture medium consisted of 45\% RPMI-1640 medium, 45\% AIM-V medium (Gibco BRL, Walkersville, MA, USA), $10 \%$ fetal calf serum, $100 \mathrm{IU} / \mathrm{ml}$ of interleukin (IL)-2 and 0.1 $\mu \mathrm{M}$ MEM non-essential amino acid solution (Gibco BRL). Half of the medium was removed and replaced with new medium containing a corresponding peptide $(20 \mu \mathrm{M})$ every 3 days. 
Table I. Vaccine candidate peptides.

\begin{tabular}{|c|c|c|c|c|}
\hline HLA & Peptide name & Mother protein & a.a. Position & a.a. Sequence \\
\hline \multicolumn{5}{|c|}{ HLA-A2 } \\
\hline & SART3-302 & SART3 & $302-310$ & LLQAEAPRL \\
\hline & СурB-129 & Cyclophilin B & $129-138$ & KLKHYGPGWV \\
\hline & Lck-246 & p56 lck & $246-254$ & KLVERLGAA \\
\hline & Lck-422 & p56 lck & $422-430$ & DVWSFGILL \\
\hline & ppMAPkkk-432 & ppMAPkkk & $432-440$ & DLLSHAFFA \\
\hline & WHSC2-103 & WHSC2 & $103-111$ & ASLDSDPWV \\
\hline & UBE2V-43 & UBE2V & $43-51$ & RLQEWCSVI \\
\hline & HNRPL-501 & HNRPL & $501-510$ & NVLHFFNAPL \\
\hline \multicolumn{5}{|c|}{ HLA-A24 } \\
\hline & SART2-93 & SART2 & $93-101$ & DYSARWNEI \\
\hline & SART3-109 & SART3 & $109-118$ & VYDYNCHVDL \\
\hline & Lck-208 & p56 lck & $208-216$ & HYTNASDGL \\
\hline & Lck-488 & p56 lck & $488-497$ & DYLRSVLEDF \\
\hline & MRP3-1293 & MRP3 & 1293-1302 & RYLTQETNKV \\
\hline & PAP-213 & PAP & $213-221$ & LYCESVHNF \\
\hline & PSA-248 & PSA & $248-257$ & HYRKWIKDTI \\
\hline & EGF-R-800 & EGF-R & $800-809$ & DYVREHKDNI \\
\hline \multicolumn{5}{|c|}{ HLA-A3 supertype } \\
\hline & SART3-511 & SART3 & $511-519$ & WLEYYNLER \\
\hline & SART3-734 & SART3 & $734-742$ & QIRPIFSNR \\
\hline & Lck-90 & p56 lck & $90-99$ & ILEQSGEWWK \\
\hline & Lck-449 & p56 lck & $449-458$ & VIQNLERGYR \\
\hline & PAP-248 & PAP & $248-257$ & GIHKQKEKSR \\
\hline & PSA-16 & PSA & $16-24$ & GAAPLILSR \\
\hline & IEX1-47 & IEX-1 & $47-56$ & APAGRPSASR \\
\hline & $\beta$-tubulin5-154 & $\beta$-tubulin5 & $154-162$ & KIREEYPDR \\
\hline
\end{tabular}

After incubation for 14 days, these cells were harvested and tested for their ability to produce interferon (IFN)- $\gamma$ in response to T2, CIR-A11, CIR-A24, CIR-A31 or CIR-A33 cells (stable transformants of CIR cells with HLA-A1101, -A2402, -A31012 and -A3303, respectively) that were preloaded with either a corresponding peptide or a negative control peptide from human immunodeficiency virus (HIV) as reported previously (8-13). The level of IFN- $\gamma$ was determined by enzyme-linked immunosorbent assay (limit of sensitivity, $10 \mathrm{pg} / \mathrm{ml}$ ). All assays were carried out in quadruplicate and were analyzed by the Student's t-test. The peptide-specific IFN- $\gamma$ production (net value) was estimated as the difference between the IFN- $\gamma$ production in response to target cells with a corresponding peptide and the IFN- $\gamma$ production in response to target cells with an HIV peptide; differences of $\mathrm{P} \leq 0.05$ were considered statistically significant. The IFN- $\gamma$ production of individual wells in the quadruplicate cultures was considered positive when the net value was $>50 \mathrm{pg} / \mathrm{ml}$.

Measurement of peptide-specific IgGs. The peptide-specific IgG levels were measured using a Luminex system (Luminex, Austin, TX, USA) as reported previously $(8,10)$. In brief, plasma was incubated with $25 \mu$ l of peptide-coupled color-coded beads for $2 \mathrm{~h}$ at room temperature on a plate shaker. After incubation, the mixture was washed with a vacuum manifold apparatus and incubated with $100 \mu \mathrm{l}$ of biotinylated goat anti-human IgG ( $\gamma$-chain specific) for $1 \mathrm{~h}$ at room temperature. The plate was then washed, followed by the addition of $100 \mu \mathrm{l}$ of streptavidinphycoerythrin per well and incubation for an additional $30 \mathrm{~min}$ at room temperature on a plate shaker. The bound beads were washed three times, followed by the addition of $100 \mu \mathrm{l}$ of Tween-20 phosphate-buffered saline into each well. Each sample $(50 \mu \mathrm{l})$ was then analyzed using the Luminex system.

\section{Results}

Patient characteristics. Between April 2007 and September 2008, 17 patients with different types of advanced cancer were enrolled in this study (Table II). There were 15 male and 2 female subjects, with a median age of 70 years (range 53-76). All patients had advanced-stage cancer and were previously treated with and failed to respond to the standard therapy for the particular cancer type, including surgery, chemotherapy, hormone therapy, radiation therapy or a combination of two or more of the above. There were 2 HLA-A2, 8 HLA-A24 and 12 HLA-A3 supertype-positive patients. 
Table II. Patient characteristics.

\begin{tabular}{llllll}
\hline Patient ID & HLA type & \multicolumn{1}{c}{ Disease } & Disease stage & Age/Gender ${ }^{\mathrm{a}}$ & \multicolumn{1}{c}{ Previous treatment } \\
\hline D1 & A2/A24 & Vulvar carcinoma & IVb & $76 / \mathrm{F}$ & Surgery, chemo \\
001 & A24 & Prostate cancer & D2 & $68 / \mathrm{M}$ & Hormone \\
002 & A24/A11 & Bladder cancer & IV & $63 / \mathrm{M}$ & Surgery, chemo \\
003 & A24 & Prostate cancer & D1 & $58 / \mathrm{M}$ & Hormone, chemo \\
004 & A24/A33 & Penile SCC & III & $74 / \mathrm{M}$ & Surgery, chemo-radiation \\
005 & A26/A31 & Prostate cancer & D1 & $71 / \mathrm{M}$ & Hormone \\
008 & A24 & Prostate cancer & D2 & $75 / \mathrm{M}$ & Hormone, chemo \\
009 & A24/A31 & Prostate cancer & D2 & $69 / \mathrm{M}$ & Hormone \\
010 & A24/A26 & Prostate cancer & C & $72 / \mathrm{M}$ & Hormone \\
011 & A26/A31 & Gallbladder cancer & IV & $68 / \mathrm{M}$ & Surgery, chemo, tumor-cell vaccine \\
101 & A2/A33 & Renal cell carcinoma & IV & $54 / \mathrm{M}$ & Surgery \\
301 & A11/A33 & Prostate cancer & D1 & $56 / \mathrm{M}$ & Surgery, hormone, chemo, radiation \\
302 & A11/A33 & Prostate cancer & C & $70 / \mathrm{M}$ & Hormone, chemo, radiation \\
303 & A11 & Prostate cancer & D2 & $70 / \mathrm{M}$ & Hormone \\
304 & A11/A31 & Skin SCC & III & $74 / \mathrm{M}$ & Radiation, chemo \\
305 & A11/A26 & Prostate cancer & D2 & $65 / \mathrm{M}$ & Surgery, hormone, chemo, radiation \\
306 & A11/A33 & Adorenocortical cancer & IV & $53 / \mathrm{F}$ & Surgery, chemo \\
\hline
\end{tabular}

${ }^{a}$ Median age of the patients was 70 years (range 53-76). SCC, squamous cell carcinoma.

Toxicities. The overall toxicities are shown in Table III. The most frequent adverse events were injection site reactions $(n=9)$, tumor site pain $(n=7)$ and limb edema $(n=4)$. All of the adverse events were grade 1 or 2 , with the exception of one case of tumor site pain (grade 3). Severe adverse events (grade $\geq 3$ ) were as follows: increase in serum ALT $(n=1$, grade 3$)$, increase in serum creatinine $(n=2$, grade 3$)$, rectal fistula $(n=1$, grade 3$)$, decrease of hemoglobin $(n=2$, grade $4 ; n=2$, grade 3$)$, duodenal hemorrhage $(n=1$, grade 3 ), hypotension $(n=1$, grade 4$)$, penile infection $(n=1$, grade 4$)$, lymphopenia $(n=1$, grade 3$)$, stricture of the ureter $(n=1$, grade $4, n=1$, grade 3$)$, urticaria $(n=1$, grade 3$)$ and death $(n=1$, grade 5$)$. All of the severe adverse events (grade $\geq 3$ ) observed in this study were evaluated by an independent safety evaluation committee, who concluded that the events were associated with cancer progression.

Peptides and immunological responses. The HLA-A types of the patients $(n=17)$ were HLA-A2 $(n=2),-A 11(n=4),-A 24$ $(n=8),-A 26(n=3),-A 31(n=5)$ and $-A 33(n=2)$. The numbers of peptides vaccinated to the patients were 4 peptides to 8 patients, 3 to 7 patients, and 2 to 2 patients. Post 6th vaccination, blood samples were obtained from 13 of the patients. Since 14 patients received at least six vaccinations, 13 patients were eligible for immunological analysis (Table IV). The median number of vaccinations was 12 , with a range of 6-37. Both CTL and $\mathrm{IgG}$ responses to the vaccinated peptides were analyzed in the pre- and post- (6th and 12th) vaccination samples (Table IV). The remaining 3 patients withdrew from the trial earlier due to disease progression, terminating treatment after only one, one and four vaccinations, respectively.
When the $\operatorname{IgG}$ level of the post-vaccination plasma was more than 1.5-fold higher than that of the pre-vaccination plasma, the increment was considered to be significant. When a significant increment was observed for at least one vaccinated peptide, the specific $\operatorname{IgG}$ response was considered to be augmented. Under these criteria, the peptide-specific IgG response was augmented in 8 out of 13 patients after the 6th vaccination and in all 6 patients after the 12 th vaccination.

We considered the IFN- $\gamma$ production of individual wells of the quadruplicate culture to be positive when the net value was $>50 \mathrm{pg} / \mathrm{ml}$. If the number of positive wells of the post-vaccination samples increased - or in cases in which the number of positive wells was unchanged between the pre- (before the 1st vaccination) and post-vaccination samples, if the net values of positive wells increased more than 2 -fold - then the IFN- $\gamma$ response was considered to be augmented. Under these criteria, augmentation of CTL activity in response to at least one of the vaccinated peptides after the 6th and 12th vaccination was observed in 11 out of 12 and 2 out of 3 patients tested, respectively. Patient 301 had two different types of HLA-A3 supertypes (HLA-A11 and -A31), and each type-restricted CTL response to the vaccinated peptides was investigated. An augmented CTL response to the Lck-449 peptide was observed in both HLA types, whereas augmentation to the IEX-47 peptide was observed only in an HLA-A33-restricted manner (Table IV). Similarly, patient 306 had two different types of HLA-A3 supertypes (HLA-A11 and -A33), and an augmented CTL response to the SART3-511 and Lck-449 peptides was observed only in an HLA-A33restricted manner (Table IV). The SART3-109 peptide, which has the ability to induce CTL activity in PBMCs of both HLA-A24 and -A3 supertypes, but not in HLA-A2+ 
Table III. Adverse events.

\begin{tabular}{|c|c|c|c|c|c|c|c|}
\hline \multirow[t]{2}{*}{ Adverse events } & \multicolumn{5}{|c|}{ No. of patients presenting with each event } & \multirow[b]{2}{*}{ Total } & \multirow[b]{2}{*}{ Frequency $(\%)$} \\
\hline & G1 & G2 & G3 & G4 & G5 & & \\
\hline & & & & & & 0 & 0 \\
\hline Injection site reaction & 3 & 6 & & & & 9 & 52.9 \\
\hline ALT, SGPT & 1 & & 1 & & & 2 & 11.8 \\
\hline AST, SGOT & 2 & & & & & 2 & 11.8 \\
\hline Creatinine & & & 2 & & & 2 & 11.8 \\
\hline $\begin{array}{l}\text { Death not associated with CTCAE - } \\
\text { disease progression NOS }\end{array}$ & & & & & 1 & 1 & 5.9 \\
\hline Dermatology/skin-other, herpes zoster & & 1 & & & & 1 & 5.9 \\
\hline Diarrhea & 1 & & & & & 1 & 5.9 \\
\hline Edema: limb & & 4 & & & & 4 & 23.5 \\
\hline Fatigue & 2 & 1 & & & & 3 & 17.6 \\
\hline Fever & 1 & 2 & & & & 3 & 17.6 \\
\hline Fistula, GI-rectum & & & 1 & & & 1 & 5.9 \\
\hline Hemoglobin & & & 2 & 2 & & 4 & 23.5 \\
\hline Hemorrhage, GI-duodenum, stomach & & & 1 & & & 1 & 5.9 \\
\hline Hypotension & & & & 1 & & 1 & 5.9 \\
\hline Infection-other, penis & & & & 1 & & 1 & 5.9 \\
\hline Lymphopenia & & & 1 & & & 1 & 5.9 \\
\hline Pain-tumor pain & 1 & 5 & 1 & & & 7 & 41.2 \\
\hline Potassium, serum-high & & 1 & & & & 1 & 5.9 \\
\hline Somnolence & & 1 & & & & 1 & 5.9 \\
\hline Stricture/stenosis, GU-ureter & & & 1 & 1 & & 2 & 11.8 \\
\hline Urticaria & & & 1 & & & 1 & 5.9 \\
\hline Vomiting & 2 & 2 & & & & 4 & 23.5 \\
\hline
\end{tabular}

patients, was vaccinated to patient 009 (HLA-A24 and -A31). Therefore, CTL activity to the SART3-109 peptide in both an HLA-A24- and -A31-restricted manner was investigated. As a result, an augmented CTL response was observed in both the HLA types, with the HLA-A24-restricted induction being much stronger (Table IV).

\section{Discussion}

HLA restriction is the main feature of T-cell-mediated recognition of antigenic peptides on the binding groove of HLA molecules (15). Antigen epitope peptides recognized by T-cells are different in each HLA type $(4,5)$. Therefore, it is difficult to develop peptide-based cancer vaccines applicable for patients with rare types of HLAs at the industrial level.

To overcome the hurdle of HLA restriction, protein vaccines are sometime developed. Protein vaccines usually contain multi-epitope peptides, recognized by both CTLs and helper T-cells, which may cover several different HLA types. However, whole protein vaccines may also contain allergic epitopes, since some of the target molecules for cancer vaccines have been identified as allergens for atopic dermatitis (16). In addition, the protein vaccines have the following disadvantages when compared to peptide vaccines. i) Protein vaccines are biologics rather than chemicals and therefore the industrial cost of chemistry, manufacturing and control is much higher for protein vaccines than for peptide vaccines, and it is difficult to prepare many different types of proteins as candidates for personalized vaccines. ii) The relative molar contents of the epitope peptides in the protein vaccine preparations are generally lower by a factor of several tens compared to that of peptide vaccines. For these reasons, we sought to develop a peptide-based personalized vaccine applicable for virtually all patients with different types of HLAs. Our recent study demonstrated that several vaccine candidate peptides which were originally identified in HLA-A24+ patients, were recognized by CTLs of different types in an HLA-restricted manner (18). Furthermore, HLA-A11, -A31 and -A33, as well as -A3, make up the A3 supertype, and common binding motifs of antigenic peptides for these HLA types have been identified (7). Approximately $95 \%$ of Japanese possess at least one of the HLA-A2, -A24 and -A3 supertypes. Our cancer vaccine candidate peptides were derived from commonly expressed antigens in different tissue types and origins of cancer cells $(1,2)$. Therefore, the sets of 8 peptides used for each of the HLA-A2, -A24 and -A3 supertypes in this study could be applicable for the majority of Japanese cancer patients irrespective of their HLA type. These vaccine candidate 
Table IV. Peptide-specific IgG responses induced by the peptide vaccination.

\begin{tabular}{|c|c|c|c|c|c|}
\hline \multirow[t]{2}{*}{ Patient ID (HLA type) } & \multirow[t]{2}{*}{ Total no. of vaccinations } & \multirow[t]{2}{*}{ Vaccinated peptides } & \multicolumn{3}{|c|}{ Peptide-specific IgG (FIU) } \\
\hline & & & Before 1st & Post 6th & Post 12th \\
\hline 001 (A24/A24) & 28 & $\begin{array}{l}\text { SART3-109 } \\
\text { MRP3-1293 } \\
\text { PAP-213 } \\
\text { PSA-248 }\end{array}$ & $\begin{array}{r}5,043 \\
116 \\
46 \\
8,288\end{array}$ & $\begin{array}{r}19,505 \\
193 \\
5,154 \\
21,420\end{array}$ & $\begin{array}{r}19,164 \\
2,822 \\
10,168 \\
24,132\end{array}$ \\
\hline 002 (A11/A24) & 16 & $\begin{array}{l}\text { SART3-511 } \\
\text { SART3-734 } \\
\text { SART2-93 } \\
\text { SART3-109 }\end{array}$ & $\begin{array}{r}71 \\
11 \\
10 \\
531\end{array}$ & $\begin{array}{r}333 \\
<10 \\
\mathbf{2 0} \\
450\end{array}$ & $\begin{array}{l}417 \\
<10 \\
154 \\
359\end{array}$ \\
\hline 003 (A24/A24) & 9 & $\begin{array}{l}\text { SART2-93 } \\
\text { SART3-109 } \\
\text { lck-488 } \\
\text { MRP3-1293 }\end{array}$ & $\begin{array}{r}22 \\
945 \\
18 \\
16\end{array}$ & $\begin{array}{r}22 \\
7,675 \\
17 \\
16\end{array}$ & $\begin{array}{l}\text { ND } \\
\text { ND } \\
\text { ND } \\
\text { ND }\end{array}$ \\
\hline 008 (A24/A24) & 29 & $\begin{array}{l}\text { SART3-109 } \\
\text { PAP-213 }\end{array}$ & $\begin{array}{r}79 \\
179\end{array}$ & $\begin{array}{r}2,826 \\
428\end{array}$ & $\begin{array}{r}38,887 \\
2,322\end{array}$ \\
\hline 009 (A24/A31) & 25 & $\begin{array}{l}\text { SART3-109 } \\
\text { SART3-734 } \\
\text { PAP-248 }\end{array}$ & $\begin{array}{r}544 \\
242 \\
34\end{array}$ & $\begin{array}{r}527 \\
241 \\
34\end{array}$ & $\begin{array}{r}18,131 \\
1,636 \\
38\end{array}$ \\
\hline 010 (A24/A26) & 8 & $\begin{array}{l}\text { SART3-109 } \\
\text { lck-488 } \\
\text { MRP3-1293 } \\
\text { PAP-213 }\end{array}$ & $\begin{array}{l}44 \\
98 \\
82 \\
69\end{array}$ & $\begin{array}{l}45 \\
96 \\
84 \\
68\end{array}$ & $\begin{array}{l}\text { ND } \\
\text { ND } \\
\text { ND } \\
\text { ND }\end{array}$ \\
\hline 011 (A26/A31) & 11 & $\begin{array}{l}\text { SART3-109 } \\
\text { SART3-734 } \\
\text { lck-449 }\end{array}$ & $\begin{array}{l}262 \\
373 \\
204\end{array}$ & $\begin{array}{l}242 \\
627 \\
194\end{array}$ & $\begin{array}{l}\text { ND } \\
\text { ND } \\
\text { ND }\end{array}$ \\
\hline $101(\mathrm{~A} 2 / \mathrm{A} 33)$ & 18 & $\begin{array}{l}\text { CypB-129 } \\
\text { SART3-511 } \\
\text { SART3-734 }\end{array}$ & $\begin{array}{r}220 \\
802 \\
54\end{array}$ & $\begin{array}{r}105 \\
\mathbf{1 , 2 4 4} \\
25\end{array}$ & $\begin{array}{r}22,217 \\
2,467 \\
30\end{array}$ \\
\hline $301(\mathrm{~A} 11 / \mathrm{A} 31)$ & 6 & $\begin{array}{l}\text { SART3-511 } \\
\text { lck-449 } \\
\text { IEX1-47 }\end{array}$ & $\begin{array}{r}260 \\
185 \\
21\end{array}$ & $\begin{array}{l}319 \\
239 \\
<10\end{array}$ & $\begin{array}{l}\text { ND } \\
\text { ND } \\
\text { ND }\end{array}$ \\
\hline 302 (A11/A31) & 6 & $\begin{array}{l}\text { SART3-511 } \\
\text { Lck-449 } \\
\text { IEX1-47 }\end{array}$ & $\begin{array}{r}10 \\
290 \\
15\end{array}$ & $\begin{array}{l}\text { ND } \\
\text { ND } \\
\text { ND }\end{array}$ & $\begin{array}{l}\mathrm{ND} \\
\mathrm{ND} \\
\mathrm{ND}\end{array}$ \\
\hline 303 (A11/A11) & 6 & $\begin{array}{l}\text { SART3-511 } \\
\text { lck-449 } \\
\beta \text {-tubulin5-154 }\end{array}$ & $\begin{array}{r}347 \\
201 \\
93\end{array}$ & $\begin{array}{r}\mathbf{1 , 2 1 9} \\
\mathbf{5 8 7} \\
86\end{array}$ & $\begin{array}{l}\text { ND } \\
\text { ND } \\
\text { ND }\end{array}$ \\
\hline 304 (A11/A31) & 6 & $\begin{array}{l}\text { SART3-734 } \\
\text { lck-449 } \\
\text { PAP-248 }\end{array}$ & $\begin{array}{r}346 \\
312 \\
27\end{array}$ & $\begin{array}{r}267 \\
251 \\
25\end{array}$ & $\begin{array}{l}\text { ND } \\
\text { ND } \\
\text { ND }\end{array}$ \\
\hline 305 (A11/A26) & 37 & $\begin{array}{l}\text { SART3-511 } \\
\text { SART3-734 } \\
\text { lck-90 } \\
\text { lck-449 }\end{array}$ & $\begin{array}{r}231 \\
68 \\
73 \\
143\end{array}$ & $\begin{array}{r}186 \\
58 \\
53 \\
124\end{array}$ & $\begin{array}{r}744 \\
243 \\
21,307 \\
32,987\end{array}$ \\
\hline 306 (A11/A33) & 12 & $\begin{array}{l}\text { SART3-511 } \\
\text { SART3-734 } \\
\text { lck-90 } \\
\text { lck-449 }\end{array}$ & $\begin{array}{r}107 \\
38 \\
48 \\
85\end{array}$ & $\begin{array}{r}52 \\
<10 \\
40 \\
\mathbf{1 3 6}\end{array}$ & $\begin{array}{l}\text { ND } \\
\text { ND } \\
\text { ND } \\
\text { ND }\end{array}$ \\
\hline
\end{tabular}

Values in bold print indicate significant augmentation ( $>1.5$-fold higher than that of the pre-vaccination plasma) of IgG response. FIU, fluoresence intensity unit; ND, not determined. 
Table V. Peptide-specific CTL responses induced by the peptide vaccination.

\begin{tabular}{|c|c|c|c|c|c|}
\hline \multirow{2}{*}{$\begin{array}{l}\text { Patient ID } \\
\text { (HLA) }\end{array}$} & \multirow{2}{*}{$\begin{array}{l}\text { Vaccinated peptides } \\
\text { (for HLA-A type) }\end{array}$} & \multirow[t]{2}{*}{ HLA-restriction } & \multicolumn{3}{|c|}{ Peptide-specific IFN $\gamma$ production $(\mathrm{ng} / \mathrm{ml})^{\mathrm{a}}$} \\
\hline & & & Before 1st & Post 6th & Post 12th \\
\hline 001 & SART3-109 (A24) & A24 & $-(0)$ & $182,273(2)$ & ND \\
\hline \multirow[t]{3}{*}{ (A24/A24) } & MRP3-1293 (A24) & A24 & $-(0)$ & $96,267,643,60(4)$ & ND \\
\hline & PAP-213 (A24) & A24 & $-(0)$ & $-(0)$ & ND \\
\hline & PSA-248 (A24) & A24 & $-(0)$ & $1401(1)$ & ND \\
\hline 002 & SART3-511 (A11) & A11 & $-(0)$ & $-(0)$ & ND \\
\hline \multirow[t]{4}{*}{ (A11/A24) } & SART3-734 (A11) & A11 & $-(0)$ & $-(0)$ & ND \\
\hline & SART2-93 (A11) & A11 & $-(0)$ & $365(1)$ & ND \\
\hline & SART3-109 (A11/A24) & A11 & $-(0)$ & $-(0)$ & ND \\
\hline & SART3-109 (A11/A24) & A24 & ND & ND & ND \\
\hline 003 & SART2-93 (A24) & A24 & $-(0)$ & $75,58(2)$ & ND \\
\hline \multirow[t]{3}{*}{ (A24/A24) } & SART3-109 (A24) & A24 & $-(0)$ & $-(0)$ & ND \\
\hline & lck-488 (A24) & A24 & $-(0)$ & $-(0)$ & ND \\
\hline & MRP3-1293 (A24) & A24 & $-(0)$ & $-(0)$ & ND \\
\hline 008 & SART3-109 (A24) & A24 & $-(0)$ & $281,62(2)$ & ND \\
\hline (A24/A24) & PAP-213 (A24) & A24 & $-(0)$ & $-(0)$ & ND \\
\hline 009 & SART3-109 (A24/A31) & A24 & $-(0)$ & $1564,889,171(3)$ & $1261,1511,141(3)$ \\
\hline \multirow[t]{3}{*}{ (A24/A31) } & SART3-109 (A24/A31) & A31 & $-(0)$ & $84(1)$ & $46(1)$ \\
\hline & SART3-734 (A31) & A31 & $-(0)$ & $-(0)$ & $75(1)$ \\
\hline & PAP-248 (A31) & A31 & $-(0)$ & $52(1)$ & $108(1)$ \\
\hline 010 & SART3-109 (A24) & A24 & $-(0)$ & $-(0)$ & ND \\
\hline \multirow[t]{3}{*}{ (A24/A26) } & lck-488 (A24) & A24 & $-(0)$ & $-(0)$ & ND \\
\hline & MRP3-1293 (A24) & A24 & $-(0)$ & $-(0)$ & ND \\
\hline & PAP-213 (A24) & A24 & $-(0)$ & $1346(1)$ & ND \\
\hline 011 & SART3-109 (A31) & A31 & $-(0)$ & $-(0)$ & ND \\
\hline \multirow[t]{2}{*}{ (A26/A31) } & SART3-734 (A31) & A31 & $-(0)$ & $177(1)$ & ND \\
\hline & lck-449 (A31) & A31 & $-(0)$ & $-(0)$ & ND \\
\hline 101 & СypB-129 (A2) & A2 & $-(0)$ & $-(0)$ & $-(0)$ \\
\hline \multirow[t]{2}{*}{ (A2/A33) } & SART3-511 (A33) & A33 & $-(0)$ & $101,41(2)$ & $107,99(2)$ \\
\hline & SART3-734 (A33) & A33 & $-(0)$ & $-(0)$ & $-(0)$ \\
\hline 301 & SART3-511 (A11/A31) & A11 & $-(0)$ & $-(0)$ & ND \\
\hline \multirow[t]{5}{*}{ (A11/A31) } & SART3-511 (A11/A31) & A31 & $-(0)$ & $-(0)$ & ND \\
\hline & lck-449 (A1/A31) & A11 & $-(0)$ & $136,157(2)$ & ND \\
\hline & lck-449 (A1/A31) & A31 & $-(0)$ & $213(1)$ & ND \\
\hline & IEX1-47 (A11/A31) & A11 & $-(0)$ & $-(0)$ & ND \\
\hline & IEX1-47 (A11/A31) & A31 & $-(0)$ & $60(1)$ & ND \\
\hline 302 & SART3-511 (A11/A31) & A11 & ND & ND & ND \\
\hline \multirow[t]{5}{*}{ (A11/A31) } & SART3-511 (A11/A31) & A31 & ND & ND & ND \\
\hline & Lck-449 (A11/A31) & A11 & ND & ND & ND \\
\hline & Lck-449 (A11/A31) & A31 & ND & ND & ND \\
\hline & IEX1-47 (A11/A31) & A11 & ND & ND & ND \\
\hline & IEX1-47 (A11/A31) & A31 & ND & ND & ND \\
\hline 303 & SART3-511 (A11) & A11 & $-(0)$ & $-(0)$ & ND \\
\hline \multirow[t]{2}{*}{ (A11/A11) } & lck-449 (A11) & A11 & $-(0)$ & $1165,1557,719(3)$ & ND \\
\hline & $\beta$-tubulin5-154 (A11) & A11 & $-(0)$ & $-(0)$ & ND \\
\hline 304 & SART3-734 (A11/A31) & A11 & $-(0)$ & $-(0)$ & ND \\
\hline \multirow[t]{5}{*}{ (A11/A31) } & SART3-734 (A11/A31) & A31 & ND & ND & ND \\
\hline & lck-449 (A11/A31) & A11 & $-(0)$ & $-(0)$ & ND \\
\hline & lck-449 (A11/A31) & A31 & ND & ND & ND \\
\hline & PAP-248 (A11/A31) & A11 & $-(0)$ & $-(0)$ & ND \\
\hline & PAP-248 (A11/A31) & A31 & ND & ND & ND \\
\hline
\end{tabular}


Table V. Continued.

\begin{tabular}{|c|c|c|c|c|c|}
\hline \multirow{2}{*}{$\begin{array}{l}\text { Patient ID } \\
\text { (HLA) }\end{array}$} & \multirow{2}{*}{$\begin{array}{l}\text { Vaccinated peptides } \\
\text { (for HLA-A type) }\end{array}$} & \multirow[t]{2}{*}{ HLA restriction } & \multicolumn{3}{|c|}{ Peptide-specific IFN $\gamma$ production $(\mathrm{ng} / \mathrm{ml})^{\mathrm{a}}$} \\
\hline & & & Before 1st & Post 6th & Post 12 th \\
\hline \multirow{4}{*}{$\begin{array}{l}305 \\
(\mathrm{~A} 11 / \mathrm{A} 26)\end{array}$} & SART3-511 (A11) & A11 & $-(0)$ & ND & $-(0)$ \\
\hline & SART3-734 (A11) & A11 & $-(0)$ & ND & $-(0)$ \\
\hline & lck-90 (A11) & A11 & $-(0)$ & ND & $-(0)$ \\
\hline & lck-449 (A11) & A11 & $-(0)$ & ND & $-(0)$ \\
\hline \multirow{8}{*}{$\begin{array}{l}306 \\
(\mathrm{~A} 11 / \mathrm{A} 33)\end{array}$} & SART3-511 (A11/A33) & A11 & $-(0)$ & $-(0)$ & ND \\
\hline & SART3-511 (A11/A33) & A31 & $-(0)$ & $-(0)$ & ND \\
\hline & SART3-734 (A11/A33) & A11 & $-(0)$ & $-(0)$ & ND \\
\hline & SART3-734 (A11/A33) & A31 & $-(0)$ & $-(0)$ & ND \\
\hline & lck-90 (A11/A33) & A11 & $-(0)$ & $-(0)$ & ND \\
\hline & lck-90 (A11/A33) & A31 & $-(0)$ & $-(0)$ & ND \\
\hline & lck-449 (A11/A33) & A11 & $-(0)$ & $-(0)$ & ND \\
\hline & lck-449 (A11/A33) & A31 & $-(0)$ & $517(1)$ & ND \\
\hline
\end{tabular}

aValues of IFN $\gamma$ production $(\mathrm{pg} / \mathrm{ml})$ in the positive wells are indicated. The number of positive wells in the quadruplicate cultures is also shown in parenthesis. ND, not determined.

peptides could be applicable for $95-99 \%$ of Asians, $80-83 \%$ of Caucasians, $80-84 \%$ of Spanish, $81-88 \%$ of Indians and $52-66 \%$ of Blacks. Therefore, these sets of peptide vaccines may be applicable for large numbers of cancer patients with different HLA-A types worldwide.

Augmentation of CTL activity to at least one of the vaccinated peptides was observed in 11 out of 12 patients after the 6th vaccination and in 2 out of 3 cases after the 12th vaccination. The frequency of CTL augmentation was higher than in any of our previously conducted clinical trials of personalized peptide vaccines for advanced cancer patients (8-10). This may have been at least partly due to the IFA used in the trials. In this trial we used a new formulation of IFA which we designated 'NH2', whereas previously conducted trials used the commercially available ISA51 made by Seppic (Paris, France). Indeed, we found that 'NH2' was more effective than ISA51 with regard to CTL induction specific to peptides in murine models (Iseki et al, unpublished data).

We previously reported that the SART3-109 peptide induces in vitro CTL activity restricted, not only to HLA-A24, but also to the HLA-A3 supertype, but not CTL activity restricted to HLA-A2 molecules (18). We also reported that all 8 peptides used for the HLA-A3 supertype induce in vitro CTL activity restricted to HLA-A11, -A31 and -A33 molecules (11-13). Subsequently, we investigated whether these results could be replicated in vivo in 3 patients (patients 009, 301 and 306) whose PBMCs were available for study. Indeed, the results showed that the SART3-109 peptide induced CTL activity restricted to both HLA-A24 and -A31 molecules, while the Lck-449 peptide induced CTL activity restricted to both HLA-A11 and -A31 molecules, in agreement with the results from the in vitro assays. To our knowledge, this is the first study to show CTL induction restricted to two different HLA molecules in clinical trials. Similarly, this could be the first report of peptide vaccination to cancer patients with the HLA-A3 supertype.
All of the subjects enrolled in this study had failed to respond to various types of standard therapies, and the majority of the patients could not continue the 2 nd cycle of vaccination after completion of the 1st cycle. In addition, this was a phase I study designed to investigate the safety of and immune responses to a new type of personalized peptide vaccination applicable for six different HLA-A types. Therefore, the clinical effects of the vaccine were not evaluated in this study.

In conclusion, this phase I clinical study of a personalized peptide vaccine for HLA-A2, -A24 and -A3 supertype (A3, A11, A31 and A33)-positive cancer patients confirmed the safety and immunological effects of the vaccination. These results suggest that this new type of vaccine is applicable for the majority of cancer patients in Japan and other countries.

\section{Acknowledgements}

This study was supported in part by a grant from the 'HighTech Research Center' Project for Private Universities, by matching fund subsidies from the Ministry of Education, Culture, Sports, Science and Technology (MEXT) of Japan, and by Grants-in-Aid from MEXT.

\section{References}

1. Itoh K, Yamada A, Mine T and Noguchi M: Recent advances in cancer vaccines: an overview. Jpn J Clin Oncol 39: 73-80, 2009.

2. Itoh K and Yamada A: Personalized peptide vaccines: a new therapeutic modality for cancer. Cancer Sci 97: 970-976, 2006.

3. Finn OJ: Cancer immunology. N Engl J Med 358: 2704-2715, 2008.

4. Parker KC, Bednarek MA and Cokigan JE: Scheme for ranking potential HLA-A2 binding peptides based on independent binding of individual peptide side-chains. J Immunol 152: $163-175,1994$.

5. Rammensee HG, Friede T and Stevanoviic S: MHC ligands and peptide motifs: first listing. Immunogenetics 41: 178-228, 1995. 
6. Imanishi T, Akazawa T, Kimura A, Tokunaga $\mathrm{K}$ and Gojobori $\mathrm{T}$ : Allele and haplotype frequencies for HLA and complement loci in various ethnic groups. In: HLA 1991, Vol. 1. Tsuji K, Aizawa M and Sasazuki T (eds). Oxford Scientific Publications, Oxford, pp1065-1220, 1992.

7. Sidney J, Grey HM, Southwood S, Celis E, Wentworth PA, del Guercio MF, Kubo RT, Chesnut RW and Sette A: Definition of an HLA-A3-like supermotif demonstrates the overlapping peptide-binding repertoires of common HLA molecules. Hum Immunol 45: 79-93, 1996.

8. Noguchi M, Kobayashi K, Suetsugu N, Tomiyasu K, Suekane S, Yamada A, Itoh K and Noda S: Induction of cellular and humoral immune responses to tumor cells and peptides in HLA-A24 positive hormone-refractory prostate cancer patients by peptide vaccination. Prostate 57: 80-92, 2003

9. Noguchi M, Itoh K, Suekane S, Yao A, Suetsugu N, Katagiri K, Yamada A, Yamana H and Noda S: Phase I trial of patientoriented vaccination in HLA-A2-positive patients with metastatic hormone-refractory prostate cancer. Cancer Sci 95: 77-84, 2004.

10. Noguchi M, Itoh K, Suekane S, Morinaga A, Sukehiro A Suetsugu N, Katagiri K, Yamada A and Noda S: Immunological monitoring during combination of patient-oriented peptide vaccination and estramustine phosphate in patients with metastatic hormone refractory prostate cancer. Prostate 60: 32-45, 2004.

11. Takedatsu H, Shichijo S, Katagiri K, Sawamizu H, Sata M and Itoh $\mathrm{K}$ : Identification of peptide vaccine candidates sharing among HLA-A $3^{+},-\mathrm{A} 11^{+},-\mathrm{A} 31^{+}$, and $-\mathrm{A} 33^{+}$cancer patients. Clin Cancer Res 10: 1112-1120, 2004.

12. Minami T, Matsueda S, Takedatsu H, Tanaka M, Noguchi M, Uemura H, Itoh K and Harada M: Identification of SART3-derived peptides having the potential to induce cancer-reactive cytotoxic T lymphocytes from prostate cancer patients with HLA-A3 supertype alleles. Cancer Immunol Immunother 56: 689-698, 2007.
13. Naito M, Komohara Y, Ishihara Y, Noguchi M, Yamashita Y, Shirakusa T, Yamada A, Itoh K and Harada M: Identification of Lck-derived peptides applicable to anti-cancer vaccine for patients with human leukocyte antigen-A3 supertype alleles. $\mathrm{Br} \mathrm{J}$ Cancer 97: 1648-1654, 2007.

14. Hida N, Maeda Y, Katagiri K, Takasu H, Harada M and Itoh K: A simple culture protocol to detect peptide-specific cytotoxic $\mathrm{T}$ lymphocyte precursors in the circulation. Cancer Immunol Immunother 51: 219-228, 2002.

15. Bjorkman PJ, Saper MA, Samraoui B, Bennett WS, Strominger JL and Wiley DC: The foreign antigen binding site and T cell recognition regions of class I histocompatibility antigens. Nature 329: 512-518, 1987

16. Wheatley AP, Bolland DJ, Hewitt JE, Dewar JC and Hall IP: Identification of the autoantigen SART-1 as a candidate gene for the development of atopy. Hum Mol Genet 11: 2143-2146, 2002.

17. Terasaki Y, Shichijo S, Niu Y, Komatsu N, Noguchi M, Todo S and Itoh K: An HLA-A3-binding prostate acid phosphatasederived peptide can induce CTLs restricted to HLA-A2 and -A24 alleles. Cancer Immunol Immunother 58: 1877-1885, 2009.

18. Mohamed ER, Naito M, Terasaki Y, Niu Y, Gohara S, Komatsu N, Shichijo S, Itoh K and Noguchi M: Capability of SART3(109-118) peptide to induce cytotoxic T lymphocytes from prostate cancer patients with HLA class I-A11, -A31 and -A33 alleles. Int J Oncol 34: 529-536, 2009. 